\begin{tabular}{|c|c|c|c|c|c|c|}
\hline \multirow{4}{*}{ Impact Factor: } & ISRA (India) & $=3.117$ & SIS (USA) & $=0.912$ & ICV (Poland) & $=6.630$ \\
\hline & ISI (Dubai, UAE & $=0.829$ & РИНЦ (Russia) & $=0.156$ & PIF (India) & $=1.940$ \\
\hline & GIF (Australia) & $=0.564$ & ESJI (KZ) & $=8.716$ & IBI (India) & $=4.260$ \\
\hline & JIF & $=1.500$ & SJIF (Morocco) & $=5.667$ & OAJI (USA) & $=0.350$ \\
\hline
\end{tabular}

\section{SOI: 1.1/TAS DOI: 10.15863/TAS International Scientific Journal Theoretical \& Applied Science}

p-ISSN: 2308-4944 (print) e-ISSN: 2409-0085 (online)

Year: 2019 Issue: $06 \quad$ Volume: 74

Published: $30.06 .2019 \quad$ http://T-Science.org

SECTION 13. Geography. History. Oceanology. Meteorology.
QR - Issue

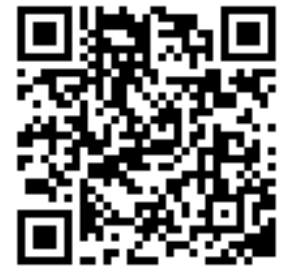

Yusufbek Sobirjonovich Jakhongirov

Andizhan State University

Senior teacher of the chair of Theory of civil society,

Republic of Uzbekistan

\title{
THE ROLE OF ISLAMIC EDUCATION INSTITUTIONS IN ENSURING SOCIAL STABILITY
}

Abstract: The article investigates the progress of large-scale performs in the field of religious education in the Republic of Uzbekistan during the years of Independence by the helping main and the internet sources.

Key words: religion, Islam, tolerance, freedom of conscience, religious confession, mosque, madrasah.

Language: English

Citation: Jakhongirov, Y. S. (2019). The role of Islamic education institutions in ensuring social stability. ISJ Theoretical \& Applied Science, 06 (74), 563-565.

Soi: http://s-o-i.org/1.1/TAS-06-74-68 Doi: crossef https://dx.doi.org/10.15863/TAS.2019.06.74.68

\section{Introduction.}

It is well known from the history that the development and development of the system of religious education in our country has a centuries-old history. The word madrasah (Arabic - a place of study, a classroom) is a medium-sized religious school in Islam, and it has prepared scholars, schoolchildren and madrassahs and religious leaders. Madrassahs, having been higher educational institutions long since, took an important place in moral educational life of the Uzbek people. The history of madrassahs which were scientific and educational institutions in the East, traces back several centuries. According to the fact by Narshahiy, a historian, the first madrassah in Mavarannahr was Farayj built in Bukhara at the beginning of $\mathrm{X}$ century. In these educational institutions, along with religious knowledge, special attention is paid to secular subjects. These topics were further explored after the independence of Uzbekistan $[1$, p.4]. It is a fact that the great scientists who contributed to the development of worldly and secular progress from these fields of science to the world's development. In the years of independence, we have been strengthening the spiritual and enlightenment fundamentals of society, introducing the basic concepts and principles of national independence, increasing the sense of responsibility and responsibility for the fate and future of our compatriots, especially the younger generation, in order to strengthen the ideological immunity against the verses, a great deal of attention has been paid to educational and educational issues, as well as significant work. Today, the challenge of combating globalism with a global educational system, while the globalization processes are increasingly increasing in the face of new threats and challenges to peace and stability. In such circumstances, the spread of information about the youth of our republic in different places, the information disseminated on our ancient Islamic religion and sacred values, spreading on the Internet and social networks, leads to such situations as the false interpretation of the sacred Islamic religion's true humanistic essence is going on [2].

\section{Research methods.}

The Qoran and hadises, muslim rights and the attitude towards the religion has a great importance in the period of the refreshment of the society. The law "on free consciousness and religious establishments"[3, p.33], adopted in 1991, determined the basis of the activity of the religious establishments and the relation of them with the state establishments, as well. In the law it has been determined that the state bodies don't interfere with the activity of the religious establishments and religious ceremonies and rights are not limited. In article 31 of our Constitution free consciousness is guaranteed. Everyone has a right to believe to any religion on not to believe according to it. And absorbing religious points is prohibited as well. On the eve of Independence, in 1989, the Uzbek language became the state language and, it was beginning of the national awakening. This step was one of the first results of independence. Attempts to 


\begin{tabular}{|c|c|c|c|c|c|c|}
\hline \multirow{4}{*}{ Impact Factor: } & ISRA (India) & $=3.117$ & SIS (USA) & $=0.912$ & ICV (Poland) & $=6.630$ \\
\hline & ISI (Dubai, UAI & $=0.829$ & РИНЦ (Russia & $=0.156$ & PIF (India) & $=1.940$ \\
\hline & GIF (Australia) & $=0.564$ & ESJI (KZ) & $=8.716$ & IBI (India) & $=4.260$ \\
\hline & JIF & $=1.500$ & SJIF (Morocco & $=5.667$ & OAJI (USA) & $=0.350$ \\
\hline
\end{tabular}

learn our moral heritage increased. Articles commenting shariat and ethics and muslim rights began to be published in press, for the first time. Trampling human rights in the Soviet period was abolished. We can see it in resetting their religious rights. Preying in the mosques, keeping "Roza" (fasting), going to "Haj visit" became usual in our life again.

A great attention is being paid to morality and enlightenment matters in Uzbekistan in the period of independence. Islam Karimov, First president of the Republic of Uzbekistan gave his thoughts thoroughly on this matter in his book "There is no future without historical memory" and emphasized the following: "The bases of the progress of the society and the only power that saves it from an inevitable destruction is enlightenment. Let's remember the events happened in Turkestan at the beginning of the century. Why did enlightenment action become stronger than ever in the country during those years? Because, the only way was enlightenment to achieve to wake up the country fell completely into decay, having been under the influence of the tsarist Russia and to raise the people".

Particularly, reforms protecting national interests and desires began to be carried out in this sphere offer Islam Karimov had been elected as the First President of Uzbek Republic. The decree of the First President of Uzbek Republic Islam Karimov "On going to "Haj visit" to Saudi Arabia". Adopted on June 2, 1990 was an important step in resetting religious rights of the Muslim and in becoming the desire of the nation true.

At the same time, the task of further developing the socio-spiritual sphere, strengthening the healthy environment in families[3], makhallas, in the whole society, the task of preserving the purity of our youth, our peaceful life and the sacred religion is of great importance today In order to regulate the essence of these issues, to solve the problems of the relevant branch system at a higher level, to ensure social stability in the country, the Presidential Decree of 16 April 2018 "On radical improvement of the religious and enlightenment sphere Resolution of the Cabinet of Ministers of the Republic of Uzbekistan from May 31, 2018 "On approval of Regulations on re-registration and liquidation of state registration of religious organizations in the Republic of Uzbekistan""On Measures to Create Additional Conditions for the Study of Foreign and Religious Education Institutions" of August 13, 2018, adopted by the Legislative Assembly - The legal documents contain a number of tasks [4]. The main problem is that we all know our community. In today's dismal period, various currents are influencing young people in their field of influence on migrants from abroad, promoting propaganda through social networking, unofficial telegraph channels, family members, neighbors. The group is engaged in the creation of secret "dormitories", publishing sources of extremist content, disseminating it electronically, and promoting missionary work [5].

According to experts, there are currently more than 100,000 websites with ideas that promote different types of extremism. Throughout the Internet, ideas such as migrating to the young, migration, martyrdom, and caliphate are being developed, and they are involved in various conflicts and conflicts. The use of extremist and terrorist movements seized by certain political powers, and the use of any commandment by the rulers in the peaceful neighborhoods of law-breaking zombie battles, the truth. The main question is, firstly, that misinterpretation of these issues is reflected in the minds of young people in educational institutions in our country, and secondly, those who contributed to world civilization in our country are still studying and In order to carry out these important tasks, the need for appropriate personnel is needed to learn the heritage of manuscripts. Particular attention should be paid to the responsibilities of the faculty, researchers, assistant students, imam-worshipers, and scholars, especially those working in religious education institutions [6].

The land of Uzbekistan is one of the ancient places of Islamic science and culture. In order to thoroughly study such rich historical, scientific, spiritual heritage of our people, to introduce them to the world public opinion, and most importantly to deeply reveal the true essence of Islam, the center of Islamic culture in Uzbekistan, the foundation of the Islamic Civilization Center in Tashkent, initiated by the President of the country, has started a new approach to the development of this sphere. In particular, the President of the Republic of Uzbekistan Sh. Mirziyoyev's initiative aims at maintaining the central architecture of the building and preserving, studying and propagating the rich scientific and spiritual heritage of great ancestors, in the future of the Islamic religion, its historical peace, and the ability to convey the essence of kindness, humanity, creativity and high morals to the members of society. Also, in the Ferghana Valley of the Central Asian region during the first years of independence, various conflicts were followed by various movements in the form of extremist, terrorist attacks, the presence of many young people, the tendency to acquire Islamic knowledge, and the great responsibility of the valley are explained. Today, there are two Islamic educational institutions in the Fergana valley [7]. "Mulla Qirg'iz" madrasah in Namangan region and Said Muhyidin Mahdum madrassah in Andizhan.

Mulla Kyrgyz Madrasa is an architectural monument to the Chorsu Square in Namangan, built in 1910-1912 due to the funds of the investor and scholar Mulla Kyrgyz Ohun Mashrabboy ugli (18501922). The Kyrgyz Madrasa, built in the central part of the city, is surrounded by five faces. The mosque 


\begin{tabular}{|c|c|c|c|c|c|c|}
\hline \multirow{4}{*}{ Impact Factor: } & ISRA (India) & $=3.117$ & SIS (USA) & $=0.912$ & ICV (Poland) & $=6.630$ \\
\hline & ISI (Dubai, UAI & $=0.829$ & РИНЦ (Russia & $=0.156$ & PIF (India) & $=1.940$ \\
\hline & GIF (Australia) & $=0.564$ & ESJI (KZ) & $=8.716$ & IBI (India) & $=4.260$ \\
\hline & JIF & $=1.500$ & SJIF (Morocco & $=5.667$ & OAJI (USA) & $=0.350$ \\
\hline
\end{tabular}

and the lecture hall were built together with one another, and they were covered with dome [8].

Andizhan "Said Muhyiddin Mahdum" Secondary Special Islamic School In 1992 the secondary specialized educational institution "Said Muhyiddin Mahdum" was established in Andizhan region. The educational institution is located in the village of Jalavek in the Altynkul district of Andizhan region, lib began his eight-year building in an uncompleted yet unfinished building [9]. Shortly afterwards, this building was fully equipped and commissioned with the help of mahallas. In these educational institutions, students are taught the secular knowledge of Islamic religion with the knowledge of the Qur'an, tajwid, fiqh, tafsir, hadith and aqeedah. Experienced teachers with many years of experience in these subjects, teachers and mentors teach. At the same time, there are a lot of initiatives for opening a school of hadeeth on separate studies and figh schools that are taught in the country in Islamic education. Today, special attention is paid to the activities of Islamic educational institutions in order to ensure social stability in the country and to study the themes of the scholars. As a result of this attention, one of the regional centers of professional development in the Republic of Uzbekistan was established in the valley for the purpose of improving the qualification of the imam-teachers and horsemen of the Ferghana Valley. In the first quarter of 2019, more than 500 "anti-agitation campaigns" were held in Fergana valley, in particular, in Andizhan. The event was organized in various educational institutions, various organizations, as a round table, seminars, trainings. Families with needy families were interviewed. For the purpose of holding these events at the highest level and achieving the results, 54 representatives from different spheres from the Ferghana Valley have been trained at a specially established 15-day training course in Tashkent [10].

\section{Conclusion.}

In summary, the role of the sacred religion of Islam and Islamic, educational institutions is remarkable in the country's stability, its peace, and its enlightenment. Therefore, the issue of skilled staff, which is responsible for bringing up the worthy successors in bringing up the worthy heroes of this noble work, bringing up the heritage of the world's heroes who have grown up in the Uzbek land, will be of interest today and tomorrow.

\section{References:}

1. Alimov, I. A. (2017). Madrasahs and schools in Kokand Khanate. (p.304). Tashkent.

2. (2018). National database of legislation date 18.04.2018 y 16/18/5416/1079 numb.

3. Karimov, I. A. (1997). Uzbekistan at the gateway of the XXI century: trouble of safety, needs of steadiness and development guarantees. (p.33). Tashkent, Uzbekistan.

4. (2018) National database of legislation date 05.06.2018/ 09/18/409/1296 numb.
5. (2018) National database of legislation date 15.08.2018/ 09/18/651/1701 numb.

6. (2019) National database of legislation date 02.02.2019 / 10/18/651/1701 numb.

7. (2019) National database of legislation date 02.02.2019/ 09/18/651/1701 numb.

8. (n.d.). Retrieved 2019, from http://madrasa.uz/uzbda-ishlab-turganmadrasalar.html 